\title{
Teachers' Accounts on their own Teaching Practices
}

\author{
Sheila Mae M. Niones
}

\author{
Bohol Is land State University - Clarin Campus
}

shel sybe@yahoo.com

\begin{abstract}
This is a qualitative study of English teachers who have at least five years of teaching experience in the Department of Education in the province of Bohol. An interview schedule was utilized in the conduct of the study using open-ended questions. NVivo 10 was used for the thematic analysis on the teachers' accounts on their teaching practices. There are three themes with subthemes extracted from the study, namely: teaching proficiency, teaching-learning process, and teaching materials. The researcher recommends the in-service English teachers to undergo self-reflection to know more of themselves as teachers and to base modifications of classroom procedures. The school administration may conduct inservice training on reflective teaching practices since these in-service English teachers do not have any seminarworkshops on reflective teaching. Action researches may be accomplished to provide empirical evidences on the improvement of the reflective teaching practices of these teachers.
\end{abstract}

Keywords- reflective teaching, teaching practices, teachers' accounts, interviews, qualitative study.

\section{INTRODUCTION}

The National Achievement Test (NAT) of the Department of Education conducted annually measures the yearly academic level, strength and weaknesses of the knowledge learned by the students. NAT examinations aim to provide information on the pupils/students' level of achievement in Grades Six, Ten, and Twelve to guide policy makers, administrators, curriculum planners, supervisors, principals and teachers for the courses of action. It also identifies and analyzes varied achievement levels by region, division, school and other variables throughout the year. It determines the occurrence of improvement in basic education per individual schools in specified time frames. In order to gauge the EFA goal in achieving quality education, NAT is national standardized test aimed and used to determine the quality of education. This is the Philippines' measure of education quality.
According to the Philippine EFA Review Report (2015)[1], the measure of education quality has been improving. As of school year 2012-2013, NAT's elementary level is 6.12 percentage away from target while NAT's secondary level is 23.59 percentage still missing from target. On the specified year, high school students had an overall MPS of 51.41 in all combined subjects. In English, the mean percentage score is 53.99; that is, almost 11 points lower than the expected MPS of 75 percent. However, the Philippines is still improving as compared to the previous eight-year NAT results but it is still far in attaining 75, the target MPS.

Due to the country's unmet targets, Philippine EFA 2015 produces a National Plan of Action. In order to attain the sixth goal which is to achieve quality teaching, teachers have to promote practice of high quality teaching (Philippine EFA Review Report, 2015)[2].

In the DepEd Region 7, a Regional Memorandum No. 54 Series of 2016, dated January 25, 2016 was communicated to recognize the 2015 Harvest of Excellence Awards to Performing Schools Division Office. The Department of Education Region 7 held Harvest of Excellence Award Program last February 1, 2016. The activity aimed to recognize significant performance of Schools Divisions and School leaders. One of categories being recognized is the Level 8 Performance Based Bonus (PBB) in the secondary schools and divisions throughout the region. One of the qualifications to get a PBB is the MPS attained by the students in the school which may also reflect teachers' effectiveness. There were twelve (12) secondary schools recognized for the said category. Among the twelve (12), six (6) secondary schools are from Bohol, namely: Lila National High School (first in rank), Pres. Carlos P. Garcia Tech-Vocational School (second), Sikatuna National Agricultural High School (fourth), Handumon National High School (fifth), Cantubod National High School (seventh), and Hingotanan National High School (eighth). 
If these schools got a PBB due to higher MPS, what do their teachers do attain such recognition? The question now is what do other teachers are doing that others are not doing? What others should be doing to attain higher MPS and achieve quality education? What makes a teacher effective?

Larrivee (2000)[3] mentioned that teachers need to realize that in their teaching profession they will be confronted continually with situations wherein they must make practical decisions. When an event or issue arises, the teachers need to realize that there is no prescribed checklist of how to respond (Mayes, 2001)[4]; they need to be able to determine an appropriate solution for that event or issue, which entails the process of reflective thinking.

Reflection is a skill necessary to possess to address abrupt situations affecting teaching-learning process. Since there is no study conducted yet related to this topic in the province of Bohol, the researcher selected the in-service English teachers in the Department of Education (DepED). These teachers have a minimum of five-year experience, because reflection is a skill learned overtime, to crisscross if reflective teaching is really practiced. This interest leads the researcher to conduct this study.

\section{OBJECTIVES OF THE STUDY}

The researcher focuses on the teachers' accounts on their own teaching practices. Specifically, the study seeks to answer the following questions:

1. What materials and resources were used for reflection?

2. How do teachers make use of these materials and resources?

3. How do teachers apply these materials and resources into practice?

4. Are the materials helpful in the teachers' reflective teaching practices? How?

5. How often do teachers make use of these materials and resources?

6. What do teachers do with these materials once utilized and conducted?

\section{MATERIALS AND METHODS}

The researcher utilized qualitative design through an interview schedule. This is used to ask questions relevant ideas for the teachers' accounts on their own teaching practices and to attain the said objective of the study.

The locales of the study were the junior high schools in the Department of Education (DepED) Bohol Division. There are three congressional districts under the
Bohol Division. A total of fifty-one (51) schools in the province of Bohol were covered in the study: the thirteen (13) schools from the first district, eighteen (18) schools from second district, and twenty (20) schools from third district.

The respondents were the in-service junior high school English teachers who are connected in the Department of Education (DepEd). These teachers are teaching English subjects in the junior high schools in the province of Bohol. They have at least reached five (5) years of teaching experience in school year 2016-2017. Of the three (3) districts in the said province, there were thirty-two (32) teachers from the first district, fifty (50) respondents from the second district while the third district had fortytwo (42) English teachers. The total number of respondents was one hundred twenty-four (124). Purposive sampling was utilized.

The instrument is the interview schedule intended for in-service English teachers. This composes six (6) openended questions leading the in-service English teachers to answer the teachers' accounts they employed in their reflective teaching practices.

The researcher secured the permission and approval of the schools division superintendent of the division of Bohol. Having the approval, the researcher interviewed the in-service English teachers.

Since the data is qualitative, NVivo 10 was used for the thematic analysis on the teachers' accounts on their teaching practices.

\section{RESULTS AND DISCUSSION}

The discussions that follow are the result of the thematic analysis on the teachers' accounts on their teaching practices. These teachers refer to the English teachers who are employed in the Department of Education (DepEd) in the Province of Bohol teaching students in junior high schools.

There are three (3) major themes in this section. These are teaching proficiency, teaching-learning process, and teaching materials. Each theme is subdivided into subthemes.

\section{Theme 1. Teaching Proficiency}

The teaching proficiency includes experience, personal and professional growth, principle, evaluation, and self-reflection.

\section{A. Experience}

Experience is the best teacher. Meador (2017)[5] even said that it remains feasibly the ultimate teacher. No 
quantity of training can really arrange for the difficulty that a teacher face in the real world. Each day and year carries approximately firsthand encounters, but experience consents teachers to adjusts hastily and create modifications confirming that things endure to function well. When teachers were asked on how teachers' accounts are applied into practice, an English teacher said:

\section{Informant 69-T2: "through observations} and live on it in and out of the classroom setting."

For the period of the initial times of profession in teaching, getting involved in responsibilities is a worthy impression. It will contribute a packed portrait of a teachers' life and will also aid to form remarkable curriculum vitae he/she can practice to locked further lasting positions (Work experience in teaching, 2018)[6]. Moreover, teaching can be a challenging career. There are periods when students can are unresponsive to learn and troublesome in the classroom atmosphere. But particular experience is the paramount method to display in what way to shot a challenging student into a committed learner (Kelly, 2017)[7] like what the informant below has stated:

Informant 27 - T2: "Yes, students are given the opportunity to express themselves. They are able to find meaning of the lessons presented by relating the lessons into real-life situations."

\section{B. Personal \& Professional Growth}

It profits a proportion of hard labor and enthusiasm to be an active teacher. Even individuals with the greatest natural teaching aptitude need to put the time essential to nurture their distinctive talent. Personal development is a serious element that all teachers must hold in order to make the most of their potential (Meador, 2017)[8]. Informants mentioned some ways to grow personally and professionally. Here are their statements:

Informant 135 - T1: "I see to it that it's all set and I also provide options. I also take close attention to the effectiveness of the materials in my teaching."

Informant 112 - T1: "yes. It (referring to I use the outputs of my students in my reflections) is helpful because it will help me to enhance my capability as an English teacher."

Assessing the effectiveness of their activities conducted inside their classes indicate that these teachers are helping themselves grow professionally as teachers. Teachers must stay systematic, committed, and proficient at multi-tasking to practice this as a positive system to advance themselves as educators (Meador, 2017)[9]. Christodoulou (2010)[10] said that becoming a reflective teacher means to participate oneself in an intricate endless process. This process is lifelong.

\section{Principle}

There is what teachers call as philosophies of education. Teaching is a multifarious, complex motion, often wanting instructors to manage manifold responsibilities and aims concurrently and compliantly (Teaching and Learning Principles, 2016)[11]. It serves as guideposts of these teachers on how they carry on their teaching practices inside and outside the classrooms. Informants have stated the importance of their own guiding principles. Here are the statements:

Informant 69 - T1: "very much helpful, I am guided in improving my teaching with the help of these materials( referring to journal writing, peer observation, student feedback, self-evaluation), and I've found out that my students have come out of their skill and showed active involvement in class activities"

Informant 112 - T2: "yes. It (referring to my teaching experiences and the outputs of students) serves as my guide for the next lesson I will teach in order to become more efficient and effective."

Actual teaching contains bring into line the three key components of instruction: learning objectives, assessments, and instructional activities (Teaching and Learning Principles, 2016)[12]. And these are what these teachers are practicing inside their classes. More than that, effective teaching encompasses highlighting the information and abilities teachers indicate to emphasize on (Teaching and Learning Principles, 2016)[13]. This is depicted as one of the informants mentioned this:

Informant 124 - T1: "by connecting the theory to practice and views the students as thinker, creator and constructor"

\section{Evaluation}

Evaluation is the process of making judgments about teachers' performance to determine the possible course of action. This will indicate the teaching performance of English teachers and will be the bases for future improvements. Larrivee (2006) [14] gave (10) ten attributes of a reflective teacher. Third of the ten attributes was on teachers who solicit feedback. And, the fourth attribute is teachers remain open to alternative perspectives. These are illustrated in the teaching performance of the English teachers.

Informant 48 - T1: "it (referring to my teaching portfolios (Iplan, class record, formative and summative notebook, other documents)) can be used by examining, recording and thinking about my 
classroom."

teaching of students both in and outside of the

Informant 69 - T1: "by letting my

students give their feedback and assess me in my teaching skills and after the class, I find time to evaluate my performance what went right and what needs to

be improved."

This depicts teachers who continually evaluate themselves to better their teaching performance and at the same time, improve themselves in the field of education. Evaluation constructed on student comment is a significant scheme in notifying and purifying teaching and unit strategy (Teaching Evaluation and Student Feedback, n.d.)[15].

Another group of evaluators who are of wealthy information are the administrators. They by nature ought to be exceptional assets of guidance to teachers. Teachers should not be scared to search for assistance. It is indispensable that administrators are available for teachers when the latter need a little help. Other teachers grow through evaluations conducted by their superiors (Meador, 2017)[16]. An informant stated:

Informant 37-T1: "comments and suggestions given by the principal/supervisor after the observation"

Administrators, through teacher assessments, are able to discern a teacher, recognize assets and flaws, and deal recommendations for enhancement (Meador, 2017)[17]. In this way, teachers help themselves grow effectively with the brilliant ideas from their approachable administrators.

\section{E. Self-reflection}

Reflection is fundamental to effective learning of educators, and students. Reflection is a groundwork assessment and is basic in becoming a professional teacher. Therefore, the topmost quality is being a reflective teacher (The Reflective Teacher, n.d) [18]. According to Ma \& Ren (2011), reflective teaching is the method of self-learning where the teacher acquires about himself/herself through discovering teaching and learning events (Rass, 2014)[19]. Teachers need to know more of them through reflective teaching practice. This is exemplified by the informants:

Informant 37 - T1: "yes, through analysis

of the result, I can evaluate my strengths and weaknesses that require enhancement or improvement."

Informant 66 - T2: "I think about on what I do, what happened and from that I can do differently next time."
These informants are really doing self-reflection to assess themselves and better correct actions that need to be addressed. Another proponent, Ahmad, et. al. (2013)[20] said that the reflective teachers are cognizant of the objectives of their learners. They design the learning experiences according to the needs and prospects of the students that help in achieving the responsiveness of students throughout teaching and learning. He further stated that reflective teaching is scrutinizing one's movements. And, reflective teachers construct promising associations between the needs and precise engagements of learners. This contention is also demonstrated by other informants:

Informant 48 - T1: "I can also use it to examine what I have learned through both personal experience and professional development activities and thereby to develop and analyze more effective approaches of my teaching... yes, by reflecting where and what lesson should I need to review. These materials are clarifying what good teaching is, providing rationale for teaching approaches, guiding my teaching behavior, and evaluatinghow effective my teaching is."

Informant 138 - T3: "yes, these materials are helpful in reflecting teaching. At the end of the day, you can recall how was your teaching done. Was the objective of the day met?"

Therefore, these English teachers are really doing self-reflection. The utmost distinct of virtuous teachers is that their practice is the consequence of vigilant reflection they also acquire lessons every time they teach, evaluate what they organize and use self-critical assessments to modify what they organize subsequently (Ofsted, 2004)[21].

\section{Theme 2. Teaching - Learning Process}

The teaching-learning process includes methodology, learning, assessment, and students' outputs.

\section{A. Methodol ogy}

Teaching methods refer to the universal philosophies, pedagogics and supervision used in classroom instruction (Teach: Make a Difference, 2017)[22]. These methods may differ depending to the preferences of the teachers or the need to use a certain method for a specified topic to be discussed. One of the informants focused on differentiated instruction, as stated:

Informant 52 - T1: "Provide different activities to the different groups of students with different intelligence." 
According to Farooq (2011)[23], individual differences viewpoints the disparity among individuals to a sole or number of features like differences on interest, attitude, values, study habits, psychomotor skills, and selfconcept. This term requires that these in-service English teachers need to differentiate their instruction due to their students' individual differences. According to Tomlinson (2000)[24], differentiation entails the efforts of educators to answer the discrepancy among students in the classroom. Teachers can single out at slightest four classroom elements: content, process, products, and learning environment. Differentiation means adapting teaching to encounter specific needs.

Other teachers specify their methodologies inside the classrooms. Here are their statements:

Informant 112 - T1: "I will enhance or use teaching strategy if ever I found the negative/not so good outcome to the performanceloutput of my students."

Informant 135 - T1: "I took stories or textsfrom booksformy students to reflect on. I use audio materials when it is something that would involve their listening skills. I let them use bond paper to draw their abstract idea of what they reflect on and paper if the latter is not available. Movie clip also can contribute more comprehension."

The examples above show that the teachers' chief role is to train and expedite student learning and inclusive conception of material, and to measure student learning done both official and casual procedures of assessment like students' portfolios, group projects and participation (Teach: Make a Difference, 2017)[25].

\section{B. Assessment}

In the student-centered teaching space, teaching and assessment are associated because students' learning is constantly dignified during teacher pedagogy (Teach: Make a Difference, 2017)[26]. These are depicted in the interviews with the English teachers. Here are their statements:

Informant 37 - T1: "I wrote an indication/a mark of success or failures on a particular group of learners."

Informant 52 - T1: "Construct/formulate questions following the different levels of questioning."

Informant 68 - T1: "assessment of the lesson as to whether I will proceed to the next topic or not."

Informant 18 - T2: "if majority of my students need remediation, I do remediation... yes, by referring it and determining the number of learners who met the target/need remediation."

Informant 132 - T4: "yes, basing on the class record, I can infer if the students have mastered the lesson or not. If it is mastered then the comment for the daily lesson log will be accomplished but if otherwise then the comment will be for enrichment or for follow-up."

Thus, assessing students' learning is of paramount concern to students and teachers as well. This connects the teaching and learning process that occurs inside and outside the classrooms. Effective teaching encompasses bring into line the three most important components of instruction: learning objectives, assessments, and instructional activities (Teaching and Learning Principles, 2016)[27].

\section{Students' Outputs}

Students' outputs help teachers assess students and at the same time help themselves what strategies to be conducted and what pointers have to be monitored. The informants have stated that students' outputs are their bases for their teaching practices. Here are their declarations:

Informant 79 - T2: "Let the students write what they learned and what happened during the week."

Informant 82 - T2: "activities and background knowledge of the students."

Informant 112 - T1: "I use the outputs of my students in my reflections."

Effective teaching implicates make straight the three foremost components of pedagogy: learning objectives, assessments, and instructional activities (Teaching and Learning Principles, 2016)[28]. Therefore, students' outputs play a prime role in identifying the effectiveness of teachers. This is also supported by Hunter (2008)[29] who stated that if teachers were not being influenced by students' outputs, then teachers are not teaching to their full potential. Thus, students' outputs have to be reflected always.

\section{Theme 3. Teaching Materials}

The teaching materials include instructional materials, multimedia, usage, frequency of use, allocation and storage, and material benefit and significance.

\section{A. Instructional Materials}

All teachers need provisions in order to ensure a prosperous classroom. Instructional materials are the utensils used in informative instructions that include dynamic learning and assessment. Ultimately, some resource a teacher uses to aid in teaching the students is 
called instructional material (Janovsky, 2017)[30]. Below are the informants' proclamations on the instructional materials used.

Informant 109 - T2: "Materials are provided with the students' Learning Modules (LM)... I used some of these resources. "Some" because there are those that are not applicable with the situation/students. They(the students) are asked to answer these tasks in their notebooks.

Informant 138 - T2: "short stories/ selections/passages which are applicable in real life situations which would help the learners to reflect in their thoughts and actions."

Informant 156 - T3: "Basically, stories from the books, songs, poetry and movies or from the internet."

The cited instructional materials are just a few of the commonly used teaching materials used by teachers in their classrooms. These materials can really help to introduce new concepts to students (Janovsky, 2017)[31] provided that these materials match the specific learning objectives. Moreover, one informant honestly said that instructional materials are much needed; here is the declaration:

Informant 18- T1: "Yes. It's hard to teach without IM's. These are very useful in an easy delivery of the lesson."

Thus, instructional materials are truly needed in the delivery of the lesson to make teaching-learning meaningful.

\section{B. Multimedia}

With the advent of technology, teachers are now focused on making teaching-learning more meaningful through the use of multimedia. Joshi (2012)[32] stated that one of the methods in refining the students' educational needs and aid in emerging English language skills is providing multimedia in the course of teaching and learning in the language laboratory. Some of the multimedia being utilized by the informants are the following:

Informant 99 - T2: "I often use LCD

Projector."

Informant 123 - T1: "Localized video showing activity a very effective and interesting material."

Informant 135 - T2: "Different forms: visual aids, laptop, CD, videos."
Informant 151 - T1: "I use materials and resources for reflection like video clips, poems, songs, stories."

The use of this multimedia in the classroom offers the students probabilities in relating with various texts that contribute a dense experience in the tasks and content of the subject. Joshi (2012)[33] added that the taking part of technology in the classroom cannot contradict generous positive opinion in refining the quality of teaching and giving numerous techniques.

\section{Usage}

The significance of the consumption of instructional materials in educational delivery is required. This is because of the significance attached to the usage of instructional materials in manipulating students' learning consequences in schools (Muraina, 2015)[34]. The usage of the instructional materials should matter because they will either make or break the purpose of using the material or defeat the expected meaningful experience gained in the discussion. Informants have stated; here are their contentions:

Informant $40 \quad-\quad T 2$ : “instructional resourcescan be used during reporting and using presentation during discussions of the topic."

Informant 48 - T1: "In short, portfolios can serve as a guide or vital component of my teaching as research process. These materials are my tools every day... These materials and resources should have specific purposes. These are the documents of my teaching, accomplishments within my discipline. Promoting learning by all students. Outline of my learning goals at the same time, will capture the complexity, depth and richness of my teaching and students learning. "

Informant 132 - T4: "the curriculum guide is my blueprint for what I need to develop for my students. The daily lesson log is also my guide on what I do in my class."

Instructional aides are not ends but means anticipated to assist a definite instructional resolve or utility (Onasanya, \&Omosewo. 2011)[35]. Thus, usage of these instructional materials needs to be parallel with the intended purpose of these resources when utilized inside the classrooms for more meaningful learning experience.

\section{Frequency of Use}

The improvement of technology has prepared accessible extensive variety of instructional materials to increment teachers' hard work in teaching-learning process 
(Muraina, 2015)[36]. The use of the instructional materials has reached a figure when it comes to its frequency of use. Here are the informants' statements:

Informant 4-T1: "If there is a dire need to integrate those materials to the day's discussions."

Informant 27 - T1: "if the curriculum

guide needs those materials, then it would be the exact and definite time."

Informant 48 - T1: "Everyday/frequently because these materials will not only help you reflect upon your teaching and learning and improve it, it will provide you with a large sample of reflections and evidence from which you will be able to use anytime."

Informant 135 - T1: "By having group activities usually. Sometimes, I prefer to use these materials when there is a need to make things clearer to my students."

The use of instructional materials when it comes to frequency may not affect students' learning given that these instructional materials are relevant to its use and to the topics being covered in the lessons. Contemporary teachinglearning claim that the essential facilities, well trained teachers, appropriate texts and instructional materials are desired to attain the purposes and goals of teaching at all levels (Muraina, 2015)[37].

\section{E. Allocation and Storage}

When teachers value the importance and effectiveness of the instructional materials, these will be kept and stored properly by the teachers. Aside from that, when proven operational, teachers disseminate its usefulness to other teachers. Taking care in the conduct of instructional materials is one of the most operative, costefficient, and effortlessly completed maintenance measures (Care, Handling, and Storage of Audio Visual Materials, n.d.)[38]. For the informants, these are their ways on the allocation and storage of instructional materials .

Informant 69 - T1: "Share with my coteacher when the result is quiet effective."

Informant 109 - T2: "I want each class to utilize those materials again (well for next year) to check who/what the students really have learned. These materials if used again will somehow give me a reason to just understand each batch of students."

Informant 130 - T2: "all this visual aid shall be kept for future use, that I understand they would be useful but most of the time it would be upgraded."
Informant 156 - T3: "These resources are kept in my email acct or my USB files for safe keeping."

These are their testimonies depicting the usefulness of the instructional materials used by the teachers. Some save it for future use while others need to improve it to make it more functional. Others want to share it to others. More than those reasons, it is better to keep the instructional materials because the procedure used to choose these materials is serious in case students and teachers with solid groundwork for accomplishment and effective teaching (4 Guide to Selecting Instructional Materials, 1999)[39].

\section{F. Material Benefit and Significance}

Usually, teachers work alone or by discipline to review and select materials; mostly follow the curriculum guide depending on its recommendation or availability. More than that, teachers always use instructional materials that are of benefit and significance to the teachers and students as well. Here are their varied statements with regards to the material benefit and significance of instructional materials.

Informant 4 - T1: "Precisely! The materials really make a difference in the student-learning process and make them feel the importance of reflective teaching... I make students feel the importance of the said materials for them to sustain interest in the classroom discussion."

Informant 96 - T2: "Definitely yes. It is very helpful to reflect on how we work with English students, what are our difficulties at the moment of teaching English to students. I think this is valuable for improving as English language teacher."

Informant 148 - T2: "Very much! Since multimedia presentation helps teaching-learning process very effective and successful."

Generally, the advantage of instructional media is to simplify connections between teachers and students so that learning undertakings are supplementary effective and efficient (Jumat, 2010)[40]. With this material benefit and significance of the instructional materials, it will help teachers to do its role in order for the latter to pay attention to other educational aspects

\section{CONCLUSIONS AND RECOMMENDATIONS}

The themes of the teachers' account on their teaching practices are categorized into three. These are 
teaching proficiency, teaching-learning process, and teaching materials. These three are subdivided into subthemes. Teaching proficiency includes experience, personal and professional growth, principle, evaluation, and selfreflection. These are the helpful pointers for the teachers to make them proficient in their teaching career. Aside from that, teaching-learning process includes methodology, learning, assessment, and students' outputs. These are needed to have meaningful learning experience inside the class where teachers are the facilitators of learning. Lastly, teaching materials include instructional materials, multimedia, usage, frequency of use, allocation and storage, and material benefit and significance. These specify the goodness of the consumption of teaching materials of these teachers. Teachers' account on their teaching practices, as asked, offer different views from the in-service English teachers that the lack of idea on reflective teaching is ascertained.

In relation to the results of the study, the researcher recommends the in-service English teachers to undergo selfreflection to know more of themselves as teachers and to base modifications of classroom procedures. The school administration may conduct in-service training on reflective teaching practices since these in-service English teachers do not have any seminar-workshops on reflective teaching. Action researches may be accomplished to provide empirical evidences on the improvement of the reflective teaching practices of these in-service English teachers.

\section{ACKNOWLEDGEMENT}

Commission on Higher Education K-12 Transition Program Scholarship- Dis sertation Grant

\section{REFERENCES}

[1] Philippine EFA Review Report (2015)

[2] Larrivee, B. (2000). Transforming teacher practice: Becoming the critically reflective teacher. Reflective Practice, 1(3), 293-307.

[3] Mayes, C. (2001). Deepening our reflectivity.The Teacher Educator, 36(4), 248- 264.

[4] Meador, D. (2017). Whys to Enhance Personal Growth and Development for Teachers.

[5] Work experience in teaching (2018)

[6] Kelley, M. (2017). My best teaching experience; turning classroom mis behavior into triumph

[7] Meador, D. (2017). Whys to Enhance Personal Growth and Development for Teachers.

[8] Ibid
[9] Christodoulou, I. (2010). Teacher selfreflection.Unpublished thesis of Masaryk University.

[10] Teaching and Learning Principles (2016)

[11] Larrivvee, B. (2006). An educator's guide to teacher reflection. Boston, MA: Houghton Mifflin Company.

[12] Teaching Evaluation and Student Feedback. (n.d.)Southern Cross University

[13] Meador, D. (2017). Whys to Enhance Personal Growth and Development for Teachers.

[14] The reflective teacher. Teaching in the Lifelong learning Sector.

[15] Rass, R. A. (2014). Developing reflective skills among efl student teachers. International Journal of English Language Teaching. 3. 1-14

[16] Ahmad, I., et.al. (2013). How reflective practice improves teachers' classroom teaching skill? Case of Community Based Schools in District Chitral, Kyber Pakhtunkhwa. Academic Research International: Social Sciences and Humanities. 1. 73 - 81

[17] Ofsted. (2004). Why colleges succeed.HMI 2409. UK: Crown

[18] Teach: Make a Difference. (2017).

[19] Farooq, Umar (2011). What is individual Differences, Causes \& Types of Individual Differences

[20] Tomlins on,C. A. (2000). Differentiation of Instruction in the Elementary Grades. ERIC Digest. ERIC Clearinghouse on Elementary and Early Childhood Education

[21] Teach: Make a Difference. (2017).

[22] Hunter, S. (2008). Using student output.

[23] Janovsky, A. (2017). Instructional materials: definition, examples \& evaluation.

[24] Joshi, A. (2012). Multimedia: a technique in teaching process in the classroom. Curr World Environ 2012; 7(1):33-36.doi: http://dx.doi.org/10,12944/CW E.7.1.05

[25] Muraina, M. (2015).Relevance of the use of instructional materials in teaching and pedagogical delivery: An overview. Handbook.Of Research on Enhancing Teacher Education with Advanced Instructional Technologies, 145.

[26] Onasanya,S.A. \&Omosewo, E.O. ( 2011). Effect of improvised and standard instructional materials on secondary schoolstudents' academic performance in physics in Ilorin, Nigeria.Signapore Journal of Scientifc Research. 
[27] Muraina, M. (2015).Relevance of the use of

instructional materials in teaching and pedagogical delivery: An overview. Handbook. Of Research on Enhancing Teacher Education with Advanced Instructional Technologies, 145.

[28] Care, Handling, and Storage of Audio Visual Materials. (n.d.). The Library of Congress

[29] Jumat, (2010). Instructional Media: Benefits of instructional media 